ISSN 2078-6441. Вісник Львівського університету. Серія географічна. 2018. Випуск 52. С. 143-151.

Visnyk of the Lviv University. Series Geography. 2018. Issue 52. P. 143-151.

http:/ / dx.doi.org/10.30970/vgg.2018.52.10180

$551.4(477.43)$

кс н олтун

ьвівський н ціон льний університет імені в н

вул. . орошенк , 41, 79007, м. ввів, кр їн, e-mail: oksana.koltun@lnu.edu.ua

сув у четвертинних лес х ст вся у б лці н лівому березі р. мець, обмежений вулицями итрополит ептицького н 3 ході, упрін н півночі, провулком етлюрин сході (140-250 м н схід від ділянки), двом ст вк ми н півдні. ереп д висот від вул. упрін до з пл ви мця ст новить 42 м, довжин 3 півночі н південь -820 м, м ксим льн ширин -390 м. скільки точні д ти зсувних зрушень, т кож геологічні, к ртогр фічні чи інші м тері ли т кого типу н ч с зсуву ( це кінець 1950-х років для першого зсуву і перш половин 1970-х років для другого) не зн йдені, то це дослідження - підсумок реконструкції геоморфологічної будови території 3 великом сшт бними к рт ми і пл н ми кінця -поч тку ст. ісля зсуву 6 лк і прилеглі ділянки лесового пл то з зн ли суттєвих морфологічних змін, і в суч сному рельєфі з мість схилів т поверхонь різної крутості й генезису виділяють привододільні поверхні, з будов ні без зн чного вертик льного пл нув ння; схили лесового пл то, б лок і річкової рівнини, тер сов ні під з будову; н тілі зсуву - три штучні тер си, прямовисні т круті уступи (м ксим льн висот 9 м), поверхні з моз їчним поєдн нням дрібних тер соподібних площ док, виположених схилів і уступів, дрібногорбкув ті поверхні. зик зсуву з ходив н з пл ву мця, ця ч стин зсуву згодом бул повністю змінен вн слідок спорудження греблі, д мб, ст вків і к н лу н прикінці 1980-х років. ростежено зв'язок між нтропогенними змін ми рельєфу й особливостями зсуву: н с мперед, східні і з хідні стінки відриву пов'яз ні з виїмк ми к р'єрів. уч сн нижня тер с м є приблизно ті ж бсолютні висоти, що й з хідн к р'єрн ділянк до зсуву. івнічн стінк відриву здебільшого повторює обриси брівки б лки, проте згл джує менші вигини. північному сході зсув з хопив ч стину привододільних схилів і вододільного пл то, теперішні відмітки середньої тер си близькі до рівня східного к р'єру. риродні долинні форми були знищені і зсувом, і неоднор зовим перепл нув нням території, тому ситу ція з експозицією спростил ся: 3 винятком уступів біля брівки зсуву, з площею домінують схили з південною експозицією. игнуті стовбури дерев, похилені стовпи і тріщини й інші руйнув ння споруд н досліджув ній території у 2015 р. свідч ть про розвиток повільних зсувних деформ цій і нині.

лючові слов : зсуви у міст х, зсуви в лес $\mathrm{x}$, морфологія рельєфу, місто мельницький.

сув н вул. упрін у мельницькому ст новить і теоретичний, і прикл дний інтерес, оскільки д є унік льну н году простежити, з одного боку, особливості розвитку цього процесу під нтропогенним впливом з умов помірно крутих схилів зн чної довжини з потужним лесовим покривом, з іншого - визн чити небезпеки і ризики з будови т ких схилів. руг причин н був є особливої кту льності через бр к більш прид тних земель для з будови й потреби освоєння у мельницькому т інших міст х кр їни територій з розвитком несприятливих процесів, серед яких і зсуви.

(C) олтун ., 2018 
писув ний зсув розт шов ний н лівому березі р. мець (інш н зв - удрянк ), пр вої притоки івденного угу. ін обмежений вулицями итрополит ептицького (колишня вул. скової) н 3 ході, упрін н півночі, провулком етлюри н сході (попередня н зв - провулок упрін, розт шов ний з 140-250 м н схід від ділянки), двом ст вк ми н півдні (рис. 1). ереп д висот - від 326 м н вул. упрін до 284,4 м н 3 пл ві мЦя (уріз води н 15.12 .2003 р.). овжин досліджув ної ділянки з півночі н південь від вул. упрін до кр ю д мби н мисі між ст вк ми ст новить 820 м, м ксим льн ширин - 390 м, периметр (до уступу між суч сною нижньою тер сою і дрібногорбкув тою поверхнею) - 1,3 км. лі н південь межу “язик” зсуву, відт к і периметр визн чити в жче через його вертик льне перепл нув ння для потреб меліор ції т гідротехніки у 1980-х рок х, приблизно повний периметр зсуву ст новив 1,8 км.

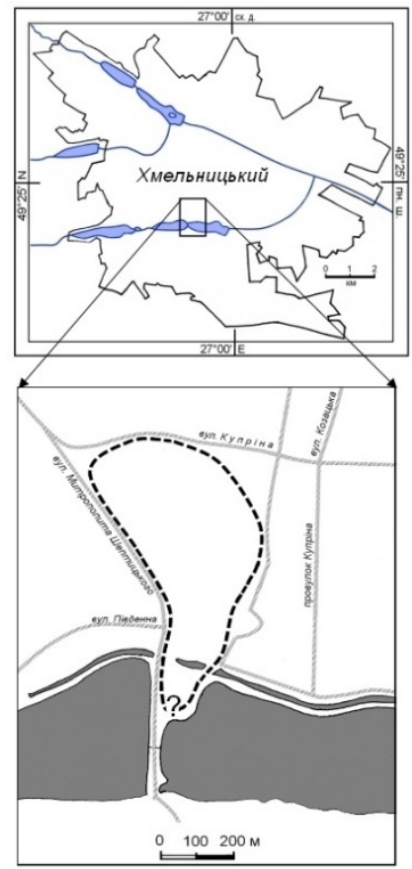

ис. 1. ок ліз ція об’єкт досліджень (штрихов лінія) і його суч сний вигляд

(тр вень 2015 p.)
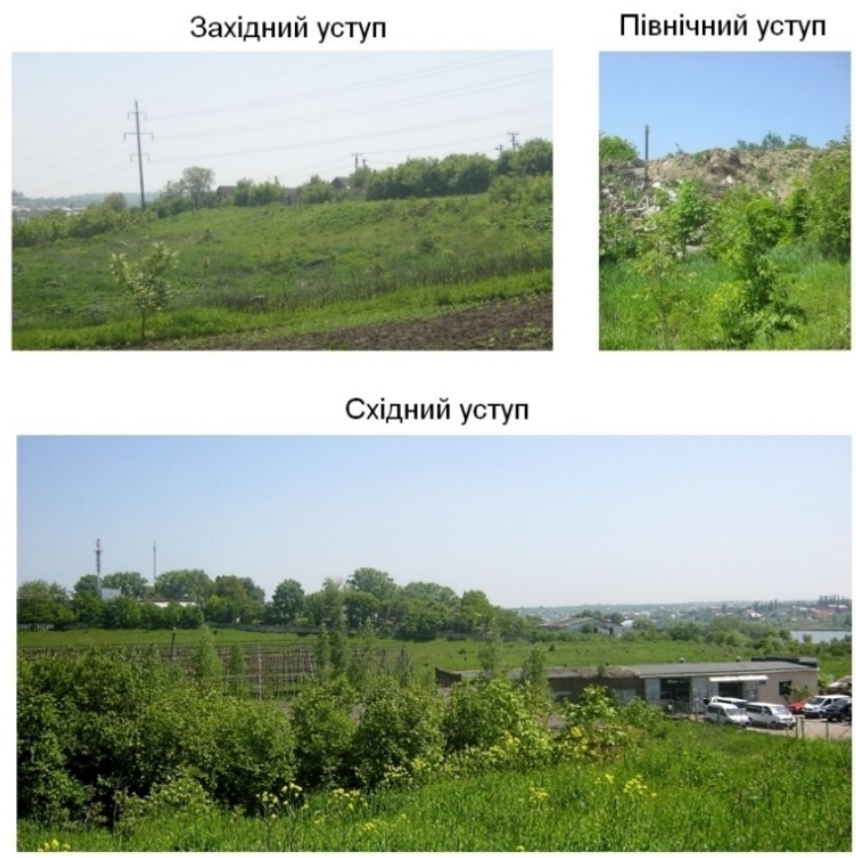

Fig. 1. Location of study object (dashed line) and its present look (May 2015)

ніше ми вже сх р ктеризув ли причини розвитку зсуву н вул. упрін $\mathrm{T}$ його м ксим льних для мельницького розмірів [2]: це поєдн ння великої кількості можливих природних і нтропогенних чинників н обмеженій території. якщо природні чинники діють і н інші потенційно зсувонебезпечні ділянки в меж х міст , то поєдн ння нтропогенних унік льне, тому с ме сукупність нтропогенних чинників (серед н йв жливіших - виїмки з обох боків у середній ч стині, б г тор зов змін конфігур ції т глибини ст ву н півдні, тр нспортне н в нт ження по периметру н 3 ході й півночі, 
знешкодження вибухових сн рядів ч сів ругої світової війни у долині мЦя) ст л резон тором особливо ктивного зсувного процесу, який трив є досі пір.

ш мет - визн чити морфологічні риси зсувної ділянки до поч тку н й ктивніших деформ цій т зміни морфології після ст біліз ції зсуву і рекультив ції території.

ля досягнення пост вленої мети використ но т кі методи: морфологічний (під ч с польових досліджень у 2015 р.), історико-к ртогр фічний, н ліз геологічних д них, фондових і літер турних джерел, т кож інтерв'ю очевидців. оловним підсумком дослідження ст ли дві геоморфологічні к рти - н ч с до зсуву (перш половин 1950-х років) ін поч ток ст.

ля побудови к рти 1950-х років використ но морфогенетичний підхід, 3 яким н цій території виокремлено флюві льно-ерозійні форми й елементи рельєфу - 3 пл в p. мець, сильносп дисті схили б лок і річкових долин (крутість $\left.-10-15^{\circ}\right)$, круті уступи комбінов ного генезису, т львеги, брівки б лок; кумулятивний рельєф лесових рівнин - дуже пологі й пологі вододільні поверхні т привододільні схили (крутість - до $4^{\circ}$ ), похилі і сп дисті схили (4-10); нтропогенний i нтропогенно змінений рельєфк р'єри, відстійники, зв лищ .

опогр фічну основу взято з к рти м сшт бу 1:10 000, знім ння орієнтовно у першій половині 1950-х ( точно ск з ти неможливо, бо номенкл турних д них н ркуш х у [6] нем є).

ля побудови к рти з суч сною ситу цією використ но фр гменти пл ну міст 1:2 000, (топознім ння 2003 і 2014 рр.) і д ні польових досліджень 2015 р. ут головний підхід для побудови к рти поляг в у виділенні морфогр фічно однорідних поверхонь, оскільки нині і територія зсуву, і прилеглі ділянки н леж ть до нтропогенного рельєфу вн слідок спрямов них (під з будову з меж ми зсуву) і вимушених з ходів вертик льного пл нув ння. ро суч сне з господ рюв ння території добре свідчить ерофотознімок 2016 р. (рис. 2). пл в мця теж повністю змінен після спорудження греблі, ст ву і к н лу н прикінці 1980-х.

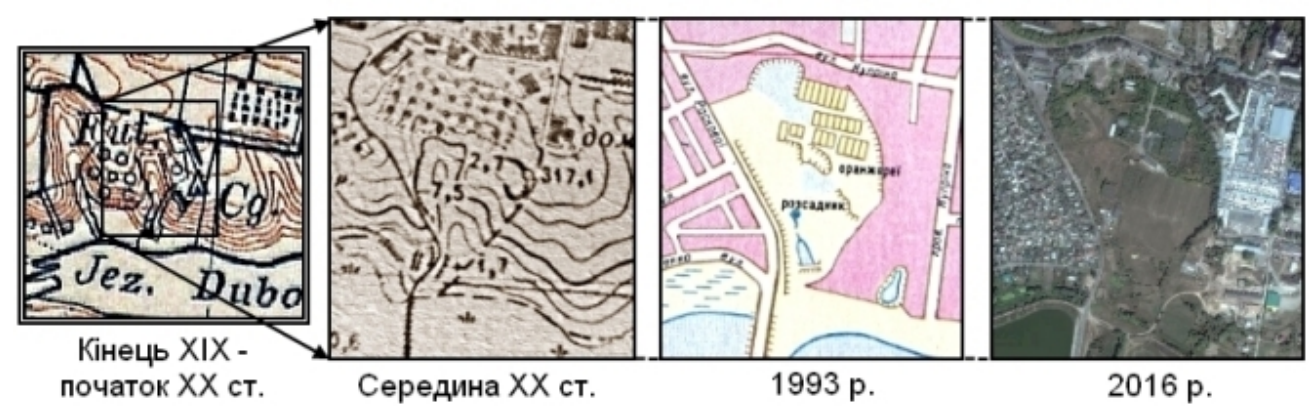

ис. 2. ериторія досліджень н к рт х, пл н х і знімк х мельницького різного ч су (2016 - знімок з Google Earth, решт - фр гменти з $[5,7,8])$

Fig. 2. Territory on maps, plans and aerial photographs of different time

(2016 - from Google Earth, other pictures are fragments of $[5,7,8])$

о морфогр фічно однорідних з числено плоскі, похилі, хвилясті чи горбисті поверхні з різним ступенем нтропогенної тр нсформ ції, т кож комбін ції їхніх фр гментів порівняно невеликих розмірів. тже, щодо зсувун н упрін можн говорити 
про привододільні поверхні, з будов ні без зн чного вертик льного пл нув ння; схили лесового пл то, б лок і річкової рівнини, тер сов ні під з будову; н тілі зсуву - тер си, прямовисні т круті уступи н тілі зсуву, поверхні з моз їчним поєдн нням тер с, виположених схилів і уступів, дрібногорбкув ті поверхні.

еологічні т гідрогеологічні особливості досліджув ної території ми розглянемо дет льніше в окремій публік ції, тут лише з зн чимо, що зсув розвинувся у плейстоценовій товщі лесово-грунтової серії потужністю пон д $30 \mathrm{M}$, як 3 ляг є н неогенових глин х, ближче до з пл ви мця - н піск х (імовірно, p нньоплейстоценових лювільних). дн к поверхня ковз ння бул не н поверхні глин, в лес х, оскільки м ксим льн висот суч сних уступів - колишніх стінок відриву - лише 9 м.

к рті кінця ст. б лк м є дв чітко вир жені витоки (див. рис. 2), у з хідному з фіксов но водотік, який почин вся з висоти 310 м. південному сході пр цює цегельня, с м к р'єр ще видно н к рт х середини ст., тоді як водотік не пок з ний. исот уступів к р'єру в середині ст. досяг л 3 м. идобуток будівельної сировини тут розпоч вся з кінця ст. у середній ч стині схилу б лки н їі лівому (східному) борті. одішня міськ вл д виділил землі в убовому для побудови військового містечк ішпит лю, т кож для цегельного з воду. межі $\mathrm{i}$ ст. це бул одн 3 шести діючих цегелень $[1,3]$. того ч су н північний схід від голови зсуву з лишил ся поверхов будівля н мисі між досліджув ною 6 лкою-зсувом і їі східною сусідкою. удівля ст ном н 2015 р. м є тріщини, різні ч стини перебув ють н відст ні 40-75 м від суч сної брівки уступу.

тому ж гіпсометричному рівні, що й к р'єр, проте н з ході території у середині

ст. був дуже крутий уступ з ввишки 7,5 м. ін, швидше з все, - теж н слідок видобутку будівельної сировини, ле може бути стінкою відриву невеликого зсуву.

кінця ст. 3 хідн ч стин верхів'їв б лки бул з йнят с д ми, з середини

ст. с д ми і виногр дник ми з с дили ще більше території. ісля зсуву круті уступи,

т кож і широку смугу біля східного уступу з ліснили різними пород ми дерев. роте смугу вируб ли кільк років тому.

ериторію н поч тку 1960-х відд ли міському упр влінню комун льного господ рств як 6 зу для зеленого господ рств, тобто для вирощув ння квітів і розс ди, для столярних м йстерень тощо, які з безпечув ли бл гоустрій міст . годом територію розділили між комун льним господ рством і р дгоспом “ віти оділля”, які освоїли лише ч стину з пон д 40 г , зн чний відсоток площі з йняли легкі конструкції теплиць і п рників. к ми з'ясув ли р ніше [2], будівлі 1962 р. (є вмуров ні д ти спорудження) розміщені нижче від укріпленого підпірною стінкою 0,5-2,5-метрового уступу, тому н йбільше зсувне зрушення прип ло н ч с між 1951 (рекогносцирув ння к рти $1: 25$ 000) i $1962 \mathrm{pp}$.

е одне зн чне зсув ння відбулося, з свідченням очевидців, н поч тку 1970-х років, коли новий уступ упритул підібр вся до г р жів і м йстерень зеленого господ рств н північному з ході ділянки. 3 ході уступи поступово виположили і підсип ють будівельним сміттям т пилом тері л ми досі. пл ні міст 1993 р. б чимо невеликий ст вок у південній ч стині, т кож з будову довкол зсуву ін ньому.

еоморфологічн ситу ція до зсуву (див. рис. 3) бул т кою: сильно сп дисті схили 6 лки доходили м йже до вододілу, по якому прокл ли вул. упрін . лк м л чотири витоки у верхів'ї, у середній ч стині н слідковий т львег прийм в ще одну притоку злів , у нижній ч стині - ще дві, зі сходу від к р’єру, другий - з з ходу від зг д ного 
крутого уступу. ксим льне перевищення брівки б лки н д н слідковим т львегом було у середній ч стині й ст новило 20 м.

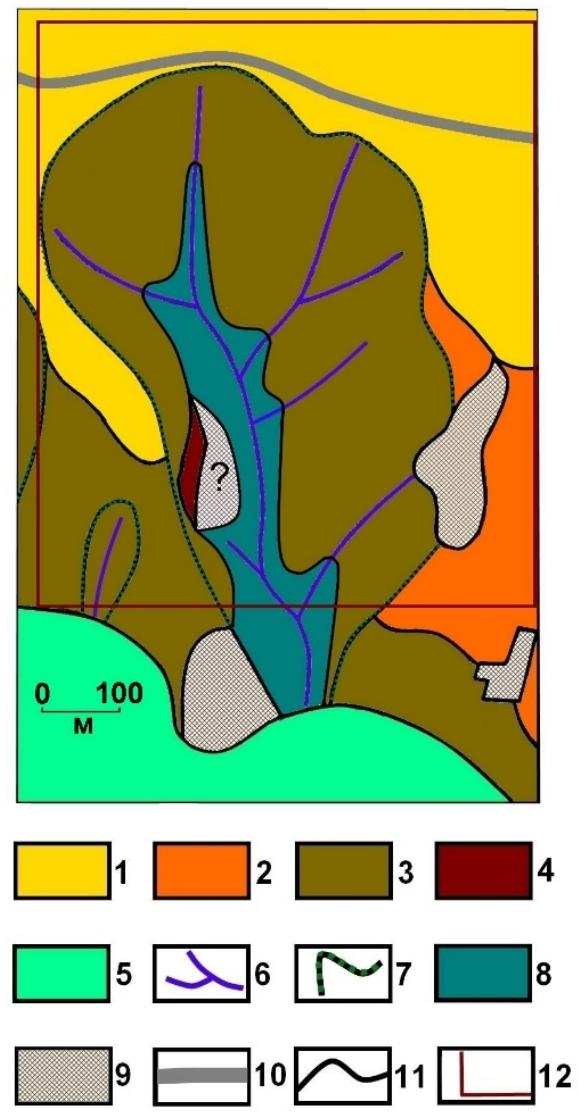

ис. 3. еоморфологічн к рт території до зсуву (середин

ст.):

1 - вододіли і привододільні поверхні кумулятивного лесового пл то, пологі і дуже пологі (крутість - до $\left.4^{\circ}\right) ; 2$ - похилі і сп дисті схили пл то $\left(4-10^{\circ}\right) ; 3$ - сильносп дисті схили 6 лок і річкової долини $\left(10-15^{\circ}\right) ; 4$ - круті уступи комбінов ного генезису; 5 - 3 пл в р. мець; 6 - т львеги; 7 - брівки 6 лок; 8 - днище 6 лки; 9 - нтропогенні форми (к р'єри, зв лище, відстійники); 10 - вулиця упрін ; 11 -інші межі; 12 - територія к рти з рис. 4.

Fig. 3. Geomorphological map of the territory before landslide (middle of the twentieth century)

ерев жн бсолютн висот субгоризонт льних ділянок, які утворилися після видобутку лесів, н сході ст новил $310-311$ м, н 3 ході-298-300 м.

ирин пригирлової ч стини б лки бул близько 80 м, тоді як після зсуву вон розширил ся вдвічі. рім к р'єру (-ів?), були ще дві зн чні нтропогенні форми - зв лище н південному з ході й відстійники н південному сході.

г лом експозиція схилу лівого берег мця південн , ле т львеги розбили досліджув ну ділянку н численні фр гменти з різними експозиціями, окрім північних: пів- 
денної, південно-східної і південно-з хідної, східної, з хідної. к з свідчили н ші попередні дослідження, суч сні зсуви у рекультивов них і з кинутих к р’єр х н території мельницького н йбільше вл стиві схил м с ме південних експозицій $[3,4]$.

оловн рис геоморфологічної ситу цї̈ н поч тку cm. - нтропогенні зміни поверхні і с мого зсуву, і прилеглих ділянок пл то, схилів т річкової долини (рис. 4). ині м ємо стінки відриву н півночі і сході з ввишки до 9 м з виход ми корінних порід і підпірними стінк ми. іло зсуву м є скл дний рельєф і від первісної б лки тут не з лишилося слідів: створені тер си для п рників і теплиць н північному сході, решт території ч стково розрівнян під городи і будівлі, ч стково м є дрібногорбкув тий рельєф.

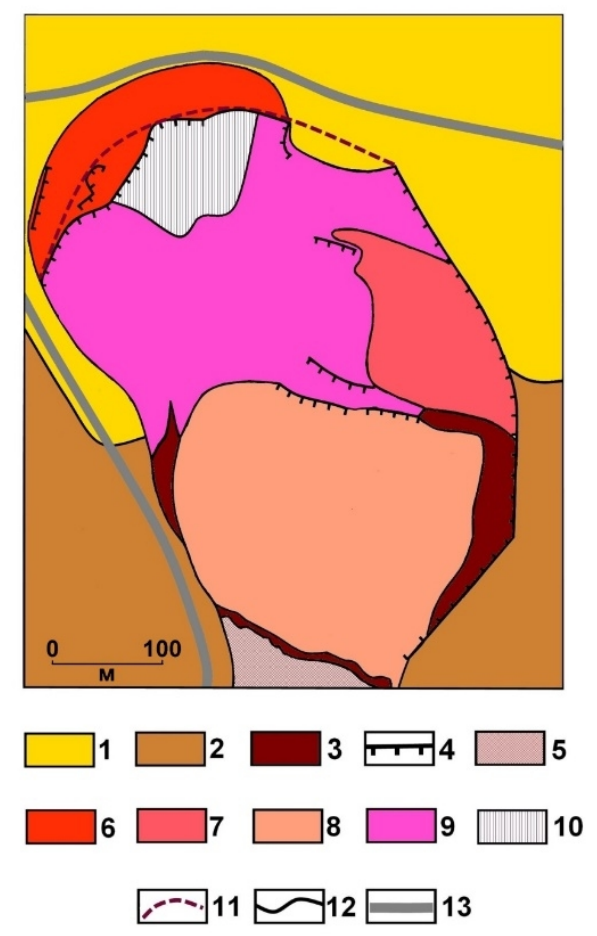

ис. 4. еоморфологічн к рт зсувун вул. упрін н поч тку

ст.:

1 - вододіли і привододільні поверхні, з будов ні без зн чного вертик льного пл нув ння; 2 - схили лесового пл то, б лок і річкової рівнини різної крутості, тер сов ні під з будову; 3-12 - тіло зсуву: 3 - дуже круті уступи; 4 - прямовисні уступи; 5 - дрібногорбкув т поверхня; 6 - верхня тер с ( бсолютні висоти - 320-324 м, н тілі зсуву ч стково), 7 - середня тер с ( бсолютні висоти - 312-313 м); 8 - нижня тер с ( бсолютні висоти 301-302 м); 9 - поверхня з моз їчним поєдн нням тер с, виположених схилів і уступів; 10 - н сип твердих виробничих відходів; 11 - реконструйов ний контур стінки відриву н північному кр ї; 12 - межі форм і поверхонь; 13 - вулиці.

Fig. 4. Geomorphological map of landslide on Kuprin St. in the beginning of twenty first century

еревищення крутих і дуже крутих уступів н д тер с ми н сході досяг є 6 м, н 3 ході - 10 м, між нижньою тер сою і дрібногорбкув тою поверхнею -5 м. рямовисні 
уступи м ють висоту від 1-2 до 9 м. ксим льн висот н північному сході $є$ між тілом зсуву і мисоподібною ділянкою між 6 лк ми з н йд внішою з будовою. овжин цієї ч стини уступу - близько 200 м, унизу він укріплений підпірною стіною з бетонних блоків. $\quad 3$ ході форм і висот уступу постійно змінюється вн слідок підсип ння відходів деревини т інших м тері лів, н ч с досліджень у квітні 2015 р. ст новил до 6 м. сувні зміщення ктивні, про що свідч ть тріщини споруд у всіх ч стин х зсуву і н віть поз його меж ми, т кож похилені стовпи т деформ ції дорожнього покриття. кщо колись були виходи природних джерел, то нині н 3 ході утворюються тимч сові водотоки вн слідок скид ння води з втомийок, які створюють промивини і н віть невеликі ярки з вглибшки до 1,5 м і 3 вширшки до 3 м.

ерхня тер с утворен вн слідок вертик льного пл нув ння території, прилеглої до північної стінки відриву зсуву, ч стково і с мого зсуву, проте його другої ф зи у 1970-х рок х. он відділен від троту ру вул. упрін підпірною стінкою з бетонних блоків, висот стінки - 0,7-1,8 м. я тер с 3 зн є повільних зсувних деформ цій, про що свідч ть тріщини будівель, дорожнього полотн і н віть 3 горожі н брівці. ксим льн ширин тер си н 3 ході - 60 м. центр льній ч стині уступ цієї тер си підсип ють відход ми деревообробки й іншими м тері л ми н площі близько 0,6 г .

ижче розт шов н поверхня без домінув ння одного типу морфогр фії, 3 чергув нням вертик льно спл нов них плоских і схилових ділянок. йнят споруд ми і город ми. овільні зсувні деформ ції спричиняють тут тріщини і руйнув ння всіх типів будівель, т кож вигин стовбурів дерев і н хил бетонних стовпів ліній електроперед ч. ередня тер с зі сходу н з хід простяг ється н 170 м, з півночі н південь - н 100 м, з йнят зруйнов ними п рник ми. ереп д між середньою і нижньою тер сою близько 11 м, н півночі - це дуже крутий і місцями прямовисний уступ з вдовжки 180 м, н 3 ході він пологіший.

ижня тер с м є м ксим льне простяг ння з з ходун схід н 250 м, 3 півночі н південь - н 200 м. ідділен крутим уступом (переп д висот - 5 м) від дрібногорбкув тої поверхні. бидві поверхня є ч стин ми язик тіл зсуву, який з зн в інтенсивних змін у південній ч стині (н рис. 4 не пок 3 н ): т м споруджені гребля, д мби, к н л.

тже, прослідковується зв'язок між нтропогенними змін ми рельєфу й особливостями зсуву: н с мперед, східні і з хідні стінки відриву пов'яз ні з виїмк ми к р'єрів. уч сн нижня тер с м є приблизно ті ж бсолютні висоти, що й з хідн к р'єрн ділянк до зсуву. івнічн стінк відриву здебільшого повторює обриси брівки б лки, проте згл джує менші вигини. північному сході зсув з хопив ч стину привододільних схилів і вододільного пл то, теперішні відмітки середньої тер си близькі до рівня східного к р'єру.

риродні долинні форми були знищені і зсувом, і неоднор зовим перепл нув нням території, тому ситу ція з експозицією спростил ся: 3 винятком уступів біля брівки зсуву, з площею домінують схили з південною експозицією. 
1. олтун . . уч сн морфологія к р'єрів ст. у м. мельницькому // ук. 3 писки умського пед. ун-ту. ер. геогр. 2016. ип. 7. . 53-63.

2. олтун . . ричини зсуву по вул. упрін у м. мельницькому // емлеустрій, к д стр т охорон земель в кр їні: суч сний ст н, європейські перспективи: тері ли міжн р. конф. (23-24 вересня 2016 р., иїв, і ). иїв: “ордон”, 2016. . 206-210.

3. олтун . . еоморфологічні процеси у к р'єр х ст. у м. мельницькому // роблеми геоморфології і п леогеогр фії кр їнських рп т і прилеглих територій. 2016. ип. 1(6). . 104-117.

4. олтун . есові к р'єри ст. у мельницькому: суч сн морфологія і морфодин мік // існик ьвів. ун-ту. ер. геогр. 2016. ип. 50. . 208-223. DOI: http://dx.doi.org/10.30970/vgg.2016.50.8696

5. опогр фическ я к рт м сшт 6 1:25 000. исты -35-90- -6, -35-90- -г, -3591- - , -35-91 - -в. енер льный шт б, 1969, 1972.

6. мельницкий. роект пл нировки город . ояснительн я з писк / иев, 1963. 386 с.

7. мельницький. [ л н міст ]. 1:17 000. . о оловне упр вління геодезії, к ртогр фії т к д стру при бінеті міністрів кр їни, 1993.

8. Płoskirów [Mapa] / Wojskowy Instytut Geograficzny. 1:100 000. Pas 51, slup 44. Warszawa, 1931. (Opracowano na podstawie map 1: 84000 wydania 1915 i 17 r. Zdjęcie oryginalne z r. 1890, 1901, 2, 7 i 8).

\section{REFERENCES}

1. Koltun, O.V. (2016). Contemporary morphology of the Khmelnytskyi City's nineteenth century quarries. Scientific Notes of Sumy State Pedagogical University. A Series of Geographical Sciences, 7, 53-63 (in Ukrainian).

2. Koltun, O.V. (2016). The reason of the landslide on Kuprin str. Khmelnytskyi City. Proceeding from International conference Land management, cadaster and land protection in Ukraine: current status and European perspective (September 23-24, 2016. Kyiv, National University of Life and Environmental Sciences of Ukraine), 206-210 (in Ukrainian).

3. Koltun, O. (2016). Geomorphological processes of Khmelnytskyi City's nineteenth century quarries. Problems of geomorphology and paleogeography of the Ukrainian Carpathians and adjacent areas, 1(6), 104-117 (in Ukrainian).

4. Koltun, O. (2016). The loess quarries of the twentieth century in Khmelnytskyi City area: contemporary morphology and geomorphological processes. Visnyk of the Lviv University. Series Geography, 50, 208-223. DOI: http://dx.doi.org/10.30970/vgg.2016.50.8696 (in Ukrainian).

5. Topographic map 1:25 000 (1969, 1972). Sheets M-35-90-G-b, M-35-90-G-g, M-35-91-V-a, M-35-91-V-v. Moscow: The Army General Staff (hence Generalnyy Shtab) (in Russian).

6. Khmelnytskyi. The city plan project. Explanatory Notes (1963). Kyiv: GIPROGRAD, 386 pp. (in Russian). 
7. Khmelnytskyi (1993). City map 1:17 000. Kyiv: Head office of Geodesy, Cartography and Cadastre at the Cabinet of Ministers of Ukraine (in Ukrainian).

8. Płoskirów [Mapa] 1:100 000 (1931). Pas 51, slup 44. Warszawa: Wojskowy Instytut Geograficzny. (Opracowano na podstawie map 1:84 000 wydania 1915 i 17 r. Zdjęcie oryginalne z r. 1890, 1901, 2, 7 i 8).

\author{
m ття: н дійшл до ред кції 12.11.2017 \\ доопр иьов н 05.01.2018 \\ прийнят до друку 06.02.2018
}

\title{
THE GEOMORPHIC FEATURES OF THE LANDSLIDE ON KUPRIN ST. IN KHMELNYTSKYI CITY
}

\author{
Oksana Koltun \\ Ivan Franko National University of Lviv, \\ P. Doroshenko St., 41, UA - 79007 Lviv, Ukraine, \\ e-mail: oksana.koltun@lnu.edu.ua
}

The landslide in Quaternary loess sediments occurs a balka at the Samets River left bank and is limited by Metropolitan Sheptytsky St. in the West, Kuprin St. in the North, Kuprin lane in the East (the last locates 140-250 m to the East of the plot), two ponds in the South. The elevation between Kuprin St. and ponds distinguish $42 \mathrm{~m}$, the length from North to South $820 \mathrm{~m}$, and the width $390 \mathrm{~m}$. The exact dates of landslide shift, as well as geological, cartographic or other materials like that at the time of sliding (the end of the 1950s for the first shift and the first half of the 1970s for the second one) were not found, this research bases on reconstruction of terrain morphology by large-scale maps, plans from the late nineteenth till early twenty-first centuries. Balka's slopes and the adjacent areas of the loess plateau undergone significant morphological changes after the landslide, modern terrain is allocated to anthropogenic surfaces, such as plane watershed, built-up without significant vertical planning; built-up terraced slopes of plateau, balkas and riverbank; three artificial terraces on the main body, as well as steep and very steep ledges and outcrops (maximum height $9 \mathrm{~m}$ ), surfaces with mosaic combination of small terraces, flattering slopes and steep ledges, hilled surface. The landslide toe came to the flood terrace; this part of the landslide was later completely changed after construction of the dam, ponds and channel in the late 1980s. There is a connection between earlier anthropogenic terrain changes and landslide: first of all, the eastern and western scarps were connected to the ledges of quarries. The modern lower terrace has approximately the same absolute heights as level of the western quarry area before sliding. The north scarp mostly repeated the contour shape of balka, but smoothed out smaller bends. In the Northeast, the landslide captured part of the plateau, the present level of the middle terrace is close to the eastern quarry level. Because of landsliding and repeated redevelopment of the territory, the situation with the slope exposures was simplified: except for the scarps, southern exposures dominate. In 2015 curved tree trunks, tilted poles, cracks and other destruction of buildings indicate the slow earthflow within area.

Key words: urban landslides, loess landslides, terrain morphology, Khmelnytskyi City. 